\title{
ANALYSIS OF THE EFFECTIVENESS OF SUSTAINABLE FOOD HOUSE AREA PROGRAM (KRPL) IN UTILIZATION OF YARD LAND IN BANDA ACEH
}

\author{
Mahrunnisa* \\ Graduate Study Program of Agribusiness, Syiah Kuala University, Banda Aceh, Indonesia
}

Agussabti and Suyanti Kasimin

Faculty of Agriculture, Syiah Kuala University, Banda Aceh, Indonesia

*E-mail: mahrunnisa.salman78@yahoo.com

\begin{abstract}
The KRPL program is a breakthrough that could increase the ability of communities in terms of farming, food self-sufficiency in order to meet family food needs are diverse, nutritious and healthy and ensure continuity in terms of food supply that is safe for each individual. The implementation of the KRPL program in Banda Aceh City has 9 factors includes motivation, participation, land area, age, education, work background and also the community's perspective on the yard only on aesthetic value.From nine factors which suspected to affect the effectiveness of the program, then there are three factors that significantly positive, namely: motivation $\left(X_{1}\right)$, land area $\left(X_{3}\right)$, and the intensity of the counseling $\left(X_{7}\right)$. It is meant to improve the effectiveness of the program, then increase the motivation factor, the area and intensity of extension needs to be improved.From the results of data processing shown that there are 6 factors were not significant, namely: participation $\left(X_{2}\right)$, age $\left(X_{4}\right)$, education $\left(X_{5}\right)$, jobs $\left(X_{6}\right)$, the characteristics of innovation $\left(X_{7}\right)$, grants $\left(X_{9}\right)$. These 6 factors have no significant effect because the land area that is owned is too narrow, which is less than $3 \mathrm{~m}^{2}$ so that the results obtained are low and do not affect the independence of the program.
\end{abstract}

\section{KEY WORDS}

Effectiveness, KRPL program, yard, land.

Food is a vital object that should be fulfilled by human availability for survival. Therefore, food needs for each person are the most essential rights that must be fulfilled. The availability of food is one of the important dimensions in the concept of food security that cannot be separated from other dimensions, namely accessibility (affordability) of society to food, and stability of food prices (Purwantini et al., 2005; Arifin, 2007).

Ministry of Agriculture Regulation number 15 year 2015 concerning Food Security is a condition of fulfilling food for the country to individuals which is reflected in the availability of sufficient food, both quantity and quality, safe, diverse, nutritious, and evenly distributed. Food security is a priority in overcoming hunger and malnutrition so that it becomes an important prerequisite for sustainable development. Based on the record of the Ministry of Agriculture in Ashari et al (2012) there are 100 regencies / cities in Indonesia potentially food-insecure, most Indonesian people, food consumption level is still concentrated on the main food is rice.

Bahar (2010) states that the rate of vegetable consumption in Indonesia is still low, around $40.8 \mathrm{~kg}$ per capita per year, while the FAO standard of $75 \mathrm{~kg}$ per capita per year, even the standard for healthy Indonesia $91.25 \mathrm{~kg}$ per capita per year. The Presidential Regulation dated June 6, 2009, concerning the diversification of local resource-based food consumption aims to accelerate the diversification of local resource-based food consumption through synergic collaboration between the central government, regional government and the community.

Following up the Presidential Regulation (PP) related to the diversification of food consumption, the Ministry of Agriculture in 2010 construct a concept of accelerated diversification of food consumption through a program of Sustainable Food Houses Region 
(KRPL). The KRPL program is a breakthrough that could increase the ability of communities in terms of farming, food self-sufficiency in order to meet family food needs are diverse, nutritious and healthy and ensure continuity in terms of food supply that is safe for each individual.

Banda Aceh is the most populous region in Aceh Province with a population of \pm 250 million people and an area of $61.36 \mathrm{~km} 2$. The implementation of the KRPL program in Banda Aceh began to be implemented in 2013 up to the present. The villages who participate in the KRPL program were 35 groups for a period of 5 (five) years. The implementation of the KRPL program in Banda Aceh City has various obstacles including motivation, participation, land area, age, education, work background and also how to change the community's perspective on the yard which has only been aesthetically valuable. However, the yard is also used as a family food source to fulfill the diverse, nutritious and safe food and can help maintain daily food, so as to realize the family's food security.

Based on the results of research conducted by the author in Banda Aceh, thing that has been done by the government (counseling) to the community was correct and has followed established technical guidelines, but the lack of understanding of the government (extension) on community characteristics when determining program targets for carried out KRPL activities, so that the KRPL program can run effectively as it should.

Sustainable Food House Area Programs (KRPL) in the utilization of the yard in Banda Aceh could be said to be ineffective and is influenced by several factors. However, the extent to which these factors can influence the KRPL program can not be known with certainty. it is suspected the majority of people lack a strong appeal and focus to take advantage of home gardens as an environmentally friendly yard and as designed by the Ministry of Agriculture in 2010. The lack of effectiveness of the program Sustainable Food Houses Region (KRPL) in the utilization of the yard in Banda Aceh caused by people who are not background farmers, people who have their own busyness or limitation of free time, the characteristics of the land area, age, education, occupation and the lack of motivation and participation in farming.So that, with this continuity KRPL program in urban communities is very complicated allegedly carried out, because changing the behavior and mindset of someone of diverse backgrounds is very difficult especially who are familiar with the very practical lifestyle and almost instantaneous.

Given the magnitude of the benefits gained with the implementation of KRPL, the authors are interested to analyze the factors that influence the effectiveness of the program and analyze the effectiveness of the program Sustainable Food House Area (KRPL) in Banda Aceh.

\section{LITERATURE REVIEW}

The Sustainable Food House Area (KRPL) is a settlement area formed by a group of several sustainable food household members who apply the methods of utilizing land or land resources properly, based on environmentally friendly local resources in providing family food and nutrition, and adding family income both through the efficiency of reducing family expenditure costs and the sale of the products it produces in achieving food security and family welfare on the basis of active participation that integrates with each other among households in the community (Saliem 2011).

The Sustainable Food House Area (KRPL) is an effort to lead to the adequacy and independence of household food. The development of KRPL also has the aim of reducing household expenditure costs by fulfilling their daily needs by utilizing the resources they have, as well as being able to avoid the effects of extreme climate anomalies. KRPL will be the foundation for anticipating changes in the conversion of agricultural land with conditions in the use of the land (Ministry of Agriculture, 2011).

The development of KRPL is a movement from households, hamlets up to the village level in collaboration with PKK Driving Team mothers from the provincial level to the Dasa Wisma and government agencies only function as motivators, facilitators, and stabilizers for this movement (Food and Implementing Resilience Agency Extension, 2012).KRPL are 
households that utilize the yard intensively through the management of local natural resources wisely, which ensures continuity of supply while maintaining and improving the quality, value and diversity, as well as food needs by taking into account local resources will have a positive impact on households and the environment with the use of local resources, many benefits that can be achieved namely ecological, economic, social, and health benefits for households, in the KRPL program each household is required to have one type of horticulture, livestock and fisheries.

\section{METHODS OF RESEARCH}

Location and Object of Research. The location of this research was carried out in Banda Aceh. The object of the research was carried out on household groups as participants involved in sustainable food house area program activities (KRPL). This research prioritizes the "mode" value, so that the large number of respondents is not a primary consideration (Pearson et al. 2003), but a deep understanding of each respondent was very essential.

Techniques of Sampling and Population. The sampling technique was done deliberately or purposive sampling, which is on the group management (chairman, secretary, treasurer) who receive the program, In general, the group administrator more aware and active in terms of program implementation home areas of food sustainably (KRPL) in comparison with the other members. The population determined was 54 people as respondents. consists of 9 sub-districts, each sub-district is taken by two representative villages. It means that the number of groups conducted by the research is 18 groups, each village consists of 3 people from each group.

Technique of Data Collection. The data collection was done by using a survey that is conducted interviews and based on the questionnaire that has been prepared. The aspects observed were land area, age, education, occupation, extension intensity, characteristics of innovation and government funding for KRPL participants and around the implementation of the KRPL program, namely motivation and participation in growing vegetables in the yard.

Primary data comes from the KRPL Program participants as research respondents. This primary data consists of qualitative data. Qualitative data is data that is not in the form of numbers, but is estimated by a scoring technique. Secondary data in this study were obtained from the relevant authorities, namely the Agricultural Extension Centers (BPP) Banda Aceh and other supporting publications that are related to this research.

Technique of Data Analysis. To measure the factors that influence the effectiveness of the program and the level of effectiveness of sustainable food house area programs (KRPL) using multiple linear regression analysis based on effectiveness indicators are supported by the Windows SPSS 20.0 program.

\section{RESULTS AND DISCUSSION}

Factors Which Affecting Effectiveness Program. Internal factors that influence the effectiveness of the KRPL program consist of 6 factors: Motivation, Participation, Land Area, Age, Education, and Employment.

Motivation is a desire that comes from oneself or caused by others who encourage someone to do certain activities to achieve goals.

Table 1 - Distribution of Respondents Based on Motivation

\begin{tabular}{ccccc}
\hline No & Classification & Category & Amount of Respondent & Persentage $(\%)$ \\
\hline 1 & Government program & Low & 28 & 51,85 \\
2 & Neighbor's Invitation & Medium & 20 & 37,03 \\
3 & Own & High & 6 & 11,11 \\
\hline & Amount & 54 & 100 \\
\hline
\end{tabular}

Source: Processed Data. 
Table above shows that out of 54 respondents amounted to $51.85 \%$ (28 people) are motivated by government programs, $37.03 \%$ (20 people) are motivated from a neighbor solicitation, while $11.11 \%$ (6) are motivated on their own. It was concluded that the motivation of participants in sustainable food house area programs was categorized as low.

Participants' participation in the KRPL program was seen from several activities, namely socialization meetings and demonstration plot management meetings. Participation in socialization meetings, namely the participation of someone in terms of carrying out program activities in accordance with the results that have been socialized. While the participation of the demonstration plot management is the involvement of participants to jointly manage the demonstration plot garden as an example of a shared yard.

Table 2 - Distribution of Respondents Based on Participation

\begin{tabular}{lllll}
\hline No & Classification & Category & Amount of Respondent & Percentage (\%) \\
\hline 1 & Attendance $\leq$ 4 Kali & Low & 29 & 53,70 \\
2 & Attendance 4-8 Kali & Medium & 19 & 35,18 \\
3 & Attendance $\geq 8$ Kali & High & 6 & 11,11 \\
\hline & Amount & & 54 & 100 \\
\hline
\end{tabular}

Source: Processed Data.

The data above shows that the participation of participants in the implementation of the KRPL program obtained a low category in the activities of group farmer socialization and management meetings which were only $<4$ times the number of attendees with the percentage of respondents reaching $53.70 \%$ or 29 people out of 54 respondents. The attendance of meetings with attendance levels between $4-8$ times reached $35.18 \%$ or around 19 people. Whereas those who have attendance above $>8$ times were $11.11 \%$ ( 6 people).

Land is a very important factor for farmers, even Onghokham (1984) calls land a heirloom land for farmers. The high and low income of farmers is strongly influenced by the area of land that they control, both their own, rent, or profit sharing. Likewise, it can affect farmers' decisions in the effort to prosper their families, is it enough to just farm or need to find another job. The city of Banda Aceh is located in the central area of the Capital City of Aceh Province, so that in the City area there is rarely a large yard. This is due to the city of Banda Aceh which is dominated by the building of public facilities such as Office, School, Shopping, Hotel, Restaurant, and supermarkets that less attention to their yards.

Table 3 - Distribution of Respondents Based on Area

\begin{tabular}{ccccc}
\hline No & Classification & Category & Amount of Respondent & Percentage (\%) \\
\hline 1 & $<3$ meter $^{2}$ & Very narrow & 26 & 48,14 \\
2 & 3 s/d 6 meter $^{2}$ & Narrow & 20 & 37,03 \\
3 & $\geq 6$ meter $^{2}$ & Medium & 8 & 14,81 \\
\hline & Amount & & 54 & 100 \\
\hline
\end{tabular}

Source: Processed Data.

From the table above it can be seen that most respondents have a very narrow land $<3$ $\mathrm{M} 2$ as many as $48.14 \%$, then the respondent had land measuring $3-6 \mathrm{M} 2$ was $37.03 \%$. While respondents who have land measuring $>6 \mathrm{M} 2$ as much as $8 \%$. This shows that most KRPL program participants have very narrow land, with this can affect their decision to use the yard to grow vegetables.

Age is one factor that has a large role in determining a person's ability to work. Certain types of work are often influenced by that age because they are related to the experience, physical abilities, enthusiasm, and emotional issues involved. Details of the complete data regarding the age of farmers can be seen in the table below. 
Table 4 - Distribution of Respondents Based on Age

\begin{tabular}{ccccc}
\hline No & Age Range (Year) & Age Category & Amount of Respondent & Percentage $(\%)$ \\
\hline 1 & $\leq 39$ & Young age & 10 & 18,51 \\
2 & $39-51$ & Productive age & 28 & 51,85 \\
3 & $\geq 51$ & Old age & 16 & 29,62 \\
\hline & Amount & 54 & 100 \\
\hline
\end{tabular}

Source: Processed Data.

According to BPS (2007), age levels can be classified into several categories: Young ( $<39$ years), Intermediate (39-51) and old ( $>51)$. According to Azwar, (2016) age also influences the work activities and productivity of a person, the ability to work and socialize can influence the input of new innovations that will be applied to his farm.

The above table shows that the majority of participants aged between 39-51 years $(51.58 \%)$ and partly young age (18.51\%) were aged under 39 years. The oldest age of participants is 67 years. In general, the results showed that the average age of farmers is 44 years old so these farmers could be said in the productive age category.

The level of education is formal education undertaken by the respondent. Based on the results of the study, the education level of respondents in Banda Aceh City ranged from 6 years to 15 years. In detail the education level of the respondents is listed in the following table.

Table 5 - Distribution of Respondents Based on Education

\begin{tabular}{ccccc}
\hline No & Classification & Time Lapse (Year) & Amount of Respondent & Percentage (\%) \\
\hline 1 & Low & $<9$ & 1 & 1,85 \\
2 & Medium & $9-12$ & 41 & 75,92 \\
3 & High & $\geq 12$ & 12 & 22,22 \\
\hline & & Amount & 54 & 100 \\
\hline
\end{tabular}

Source: Processed Data.

The table above shows that the education level of respondents in the city of Banda Aceh was still classified as a moderate classification, which is an average of 12 years or equivalent to a high school (SMA). This situation indicates that the respondent already has the ability to be able to support in carrying out an activity. The level of education could be influential in the development of thought patterns, receive information and facilitate communication, both between respondents and with stakeholders. Based on Act Number 20 of 2003 education could be classified into several levels, namely: 1. Low (not attending school, not completing elementary school and completing elementary school), 2. Moderate (graduating from junior high school or equivalent), and 3. High (graduating from high school, academic) and college).

Of the 54 respondents participating in KRPL, who were fully involved in the activities of the research respondents, they had diverse employment backgrounds. The background of the respondent's work can be seen in the following table.

Table 6 - Distribution of Respondents Based onJob Background

\begin{tabular}{cccc}
\hline No & Classification & Amount of Respondent & Percentage (\%) \\
\hline 1 & Housewife & 23 & 42.59 \\
2 & Employer & 7 & 12,96 \\
3 & Tailor & 3 & 5.55 \\
4 & Trader & 8 & 14.81 \\
5 & Labor Laundry & 13 & 24.07 \\
\hline & Amount & 54 & 100 \\
\hline
\end{tabular}

Source: Processed Data.

From the table above, it could be seen that the respondents' occupational background is dominated by friendly mothers reaching $42.59 \%$, this will have a positive impact on the 
implementation of the KRPL program because their free time can be used to grow vegetables. However, the results of interviews with respondents stated that all KRPL participants in all groups were not farmers, and had no experience at all in matching vegetable crops. But among them there are those who plant ornamental plants in the yard area for the beauty of his home. Some others buy fruit plants such as guava, guava honey, mango, and klengkeng that have been planted in pots, without having to do self-cultivation and intensive maintenance.

The intensity of counseling is an effort to increase the number of extension activities carried out to change behavior (knowledge, attitudes, and skills) carried out by counselingagents to farmers and communities to be willing and able to run an agricultural business.

Table 7 - Distribution of Respondents Based on Indicators of Extension Intensity

\begin{tabular}{cccc}
\hline No & Classification & Score of Percentage & Category \\
\hline 1 & The level of counseling attendance & 91,35 & Good \\
2 & Coaching & 98,14 & Good \\
3 & Engagement & 96,29 & Good \\
4 & Problem Solving & 95,06 & Good \\
5 & Encouragement of Fluency & 94,44 & Good \\
\hline & The Average \% Score Achieved & 95,05 & Good \\
\hline
\end{tabular}

Source: Processed Data.

The table above shows that the intensity of counseling in Banda Aceh City is in the good category (95.05). This means that counseling activities in the city of Banda Aceh went well according to the duties and functions of the extension staff. The course of counseling activities in Banda Aceh is not only assessed by the level of attendance of the extension agents, but also how the development techniques, involvement are carried out to solve a problem to encourage and assist participants in the smooth implementation of the KRPL program in extension activities. These kinds of things make the assessment of counseling activities stated good.

Judging from the agricultural counseling function on changes in behavior of KRPL program participants in Banda Aceh City, it would be ideal, because the more counseling programs are carried out, the higher the behavior of KRPL program participants in Banda Aceh City. Therefore, the program would be more effective as well.

Characteristics of innovation could be interpreted as traits or characters possessed by a technology that is felt or observed as a new thing for a person or group. The activities of development efforts in agriculture that are delivered through extension activities are aimed at achieving changes in the behavior of farmers and their communities covering both economic, socio-cultural, ideological, political and security aspects, for which development must be able to encourage changes that have renewal traits, which is often called innovation. In short, innovation is an idea, the latest ideas conveyed by instructors about skills, science and others. Innovation is the most important thing in the counseling process. Because innovation is the latest idea that will be conveyed to the public. So people can find out the latest things through innovation that has been determined by extension agents.

Table 8 - Distribution of respondents based on the variable characteristics of innovation introduced

\begin{tabular}{cccc}
\hline No & Classification & Percentage of Reached Score & Category \\
\hline 1 & The level of profit of the innovation applied & 73,45 & Medium \\
2 & The level of suitability of the innovations applied & 71,60 & Medium \\
3 & The level of complexity of innovation that is applied & 67,90 & Medium \\
4 & The level of ease of innovation to be tested & 68,51 & Medium \\
5 & The level of ease of innovation to apply & 70,98 & Medium \\
\hline & The Average \% of Score Achieve & 70,48 & Medium \\
\hline
\end{tabular}

Source: Processed Data. 
Table 8 shows that the characteristics of the innovation introduced to the participants KRPL program on the profit level was with a percentage score reached $73.45 \%$. Based on the degree of suitability is $71.60 \%$ or under, for the level of complexity that is $67.90 \%$ (moderate), and then at the level of ease tested in the field by participants reached ie $68.51 \%$, while the level of convenience to apply reached $70.98 \%$. This means that the characteristics were introduced to the participants readily accepted KRPL program.

In general, funding is one of the most important factors for running a program that is used to help, support and encouragement to carry out the activities.

Table 9 - Distribution of Respondents Based on Variables of Government Funds

\begin{tabular}{|c|c|c|c|}
\hline No & Classification & Percentage of Score & Category \\
\hline 1 & Accuracy in number & 75,92 & appropriate \\
\hline 2 & Accuracy in Type & 94,44 & appropriate \\
\hline 3 & Accuracy in Time & 95,67 & appropriate \\
\hline 4 & Accuracy in Target & 91,97 & appropriate \\
\hline & The Average\% of score achieved & 89,5 & appropriate \\
\hline
\end{tabular}

Source: Processed Data.

According to the table above, the accuracy of the number, the accuracy of the types, the timeliness and the accuracy of the target of financial assistance distributed to the program participants are correct with an average score of $89.5 \%$ or categorized as appropriate. Variable funds have no real relationship with the level of effectiveness of the program, due to funding production facilities (inputs) have been provided directly by the relevant agencies. So that people no longer need to find and buy these production facilities.

Level of Effectiveness of the KRPL Program. A program could be said to be effective if the program has reached its maximum goals as expected and marked by sustainability. Program sustainability is a manifestation of an action that has been implemented or implemented and is still ongoing and continuous.

Table 10 - Distribution of Respondents Based on Program Sustainability

\begin{tabular}{cccc}
\hline Classification & The Result of Score & Average Percentage (People) & Average Percentage (\%) \\
\hline The number of initial members & 3 & 30 & 100 \\
The Number of members now & 1 & 6 & 22,96 \\
The number of additional members & 0 & 0 & 0 \\
\hline
\end{tabular}

Source: Processed Data.

The table above shows that the level of sustainability of sustainable food house area (KRPL) programs in Banda Aceh City was still very low as evidenced by the number of current members who are still actively running the program only 6 people or $22.96 \%$ of the average percentage of initial members 30 people $(100 \%)$. It could be stated that the sustainability level of the KRPL program in Banda Aceh City is very low, as evidenced by the absence of a number of additional members.

The cultivation ability is the ability of a person on the basis of being learned as well as experience in terms of plant cultivation, both theoretically and practicing it in real terms to produce food production.

Table 11 - Distribution of Respondents Based on Planting Ability

\begin{tabular}{cccc}
\hline No & Classification & Percentage of Score & Category \\
\hline 1 & The ability of a pot cultivation & 93,82 & Understood \\
2 & The Ability to cultivate polybag media & 95,06 & Understood \\
3 & The ability to grow crops in beds & 75,30 & Understood \\
4 & The Ability to cultivate vertically & 67,28 & Understood \\
5 & The Ability to cultivate aquaponics & 62,34 & Less Understanding \\
6 & Ability to cultivate hydroponics & 38,80 & Less Understanding \\
\hline & The Average \% of Score Achieved & 72,1 & Understood \\
\hline
\end{tabular}

Source: Processed Data. 
Based on the table above shows that the ability to grow crops with polybag media has the highest percentage score of 95.06 with the understanding category. While the ability to grow crops hydroponically has the lowest percentage score of 38.80 in the category less understood.

Food independence is the ability of a person or family to produce a variety of food from the home yard. Food independence can guarantee the fulfillment of family food needs to the level of individuals by utilizing the potential of natural, human, social, economic and local spiritual resources in a dignified manner.

Table 12 - Distribution of Respondent Based on Family Food Independence

\begin{tabular}{cccc}
\hline No & Classification & Percentage of Score\% & Category \\
\hline 1 & Availability of vegetables & 49,32 & Less \\
2 & Availability of fruits & 42,59 & Less \\
3 & Availability of cooking ingredients & 45,06 & Less \\
4 & Availability of medicinal plants & 34,56 & Less \\
\hline & The Average \% of Score Achieved & 42,88 & Less \\
\hline
\end{tabular}

Source: Processed Data.

Based on the distribution table of respondents according to family food independence, the percentage of the score of availability of vegetables is $49.32 \%$ which is categorized as less, the percentage score in the availability of cooking ingredients is $45.06 \%$, the percentage score for fruit availability is $42.06 \%$ and the percentage score in the availability of medicinal plants there is still a lack of independence, which is $34.56 \%$. It could be stated that the variable level of family food independence was categorized as less independent with an average score of $42.88 \%$. Realizing family food independence is not easy, because the people of Banda Aceh City accustomed to getting food from mobile vegetable vendors, nearby kiosks and traditional / supermarket markets to meet their family's daily food needs. According to them, growing vegetables in the yard is an activity that can add to their daily activities. Because taking care of the household and other work is time consuming as their routine. Even if they want to use the yard, they prefer to plant ornamental plants because they were more easier to maintain without having to do special maintenance every day as well as growing vegetables.

Table 13 - Value of Fit of Models from Factors Affecting KRPL Program Effectiveness in Banda Aceh, 2018

\begin{tabular}{ccccc}
\hline Model & $\mathrm{R}$ & $\mathrm{R}$ square & Adjusted R Square & Std. Error Of the Estimate \\
\hline 1 &, $805^{\mathrm{a}}$ &, 648 &, 576 & 1,26864 \\
\hline
\end{tabular}

Source: Processed Data. Information. Predictors: (Constant), Fund Assistance $\left(X_{9}\right)$, Motivation $\left(X_{1}\right)$, Extension Intensity $\left(X_{7}\right)$, Land Area $\left(X_{3}\right)$, Education $\left(X_{5}\right)$, Employment $\left(X_{6}\right)$, Partipasi $\left(X_{2}\right)$, Applied Innovation $\left(X_{8}\right)$, Age $\left(X_{4}\right)$.

Based on Table 17 it could be seen that the fit of model value is 0.805 , this means that $80.5 \%$ of this model is relatively appropriate. The remaining 19.5 percent was influenced by other factors. Because this will show an ANOVA table which will assess the value of $F$ table and $F$ count.

Table 14 - Value of Calculations from the KRPL Program Effectiveness Model

\begin{tabular}{cccccc}
\hline Model & Sum of Squares & Df & Mean Square & F & Sig. \\
\hline Regression & 130,443 & 9 & 14,494 & 9,005 &, $000^{b}$ \\
Residual & 70,816 & 44 & 1,609 & & \\
\hline Total & 201,259 & 53 & & & \\
\hline
\end{tabular}

Source: Processed Data. Information. Predictors: (Constant), Fund Assistance $\left(X_{9}\right)$, Motivation $\left(X_{1}\right)$, Extension Intensity $\left(X_{7}\right)$, Land Area $\left(X_{3}\right)$, Education $\left(X_{5}\right)$, Employment $\left(X_{6}\right)$, Partipasi $\left(X_{2}\right)$, Applied Innovation $\left(X_{8}\right)$, Age $\left(X_{4}\right)$. 
Analysis of Factors Affecting Program Effectiveness on the Effectiveness of Sustainable Food House Area Program (KRPL). Analysis of the factors that influence the effectiveness of the program on the effectiveness of sustainable food house area programs (KRPL) is very important to determine the extent to which these variables influence each other.

Based on table 18, it can be seen that overall the factors that influence the effectiveness of the program are significant with $F_{\text {count }}$ of 1.005 greater than $F_{\text {table }}$ of 2.10. The following will show the regression coefficient of the factors that influence the effectiveness of the KRPL program in Banda Aceh.

Table 15 - Factors Influencing Effectiveness KRPL program in Banda Aceh, 2018

\begin{tabular}{|c|c|c|c|c|c|c|}
\hline \multirow{3}{*}{ No } & \multirow{2}{*}{ Variable } & \multicolumn{2}{|c|}{ Unstandardized Coefficients } & \multirow{3}{*}{$\frac{\text { Standardized Coefficients }}{\text { Beta }}$} & \multirow{3}{*}{$\begin{array}{c}\mathrm{T} \\
2.053\end{array}$} & \multirow{3}{*}{$\begin{array}{l}\text { Sig } \\
.046\end{array}$} \\
\hline & & $\mathrm{B}$ & Std. Error & & & \\
\hline & (Constant) & 7.678 & 3.740 & & & \\
\hline 1 & Motivation $\left(\mathrm{X}_{1}\right)$ & 1.295 & .289 & .648 & 4.483 & .000 \\
\hline 2 & Partipation $\left(\mathrm{X}_{2}\right)$ & -.278 & .186 & -.189 & -1.500 & .141 \\
\hline 3 & Land Area $\left(X_{3}\right)$ & .154 & .030 & .567 & 5.153 & .000 \\
\hline 4 & Area $\left(X_{4}\right)$ & .061 & .609 & .014 & .100 & .921 \\
\hline 5 & Education $\left(\mathrm{X}_{5}\right)$ & .613 & .447 & .142 & 1.373 & .177 \\
\hline 6 & $\operatorname{Job}\left(X_{6}\right)$ & .052 & .161 & .044 & .326 & .746 \\
\hline 7 & Intensity of Counseling $\left(X_{7}\right)$ & .480 & .181 & .272 & 2.654 & .011 \\
\hline 8 & Characteristic of Innovation $\left(\mathrm{X}_{8}\right)$ & -.265 & .202 & -.188 & -1.312 & .196 \\
\hline 9 & Aid $\left(X_{9}\right)$ & .440 & .252 & .165 & 1.741 & .089 \\
\hline
\end{tabular}

Source: Processed Data.

From the 9 factors that are thought to influence the effectiveness of the program, there are 3 factors that have a significantly positive effect, namely: motivation (X1), land area (X3), and intensity of instructor (X7). This means that to improve program effectiveness, the increase in motivation factors, land area and counseling intensity need to be improved.

From the processed data, it could be seen that there are 6 factors that have no significant effect, namely: participation (X2), age (X4), education (X5), work (X6), innovation characteristics (X7), funding assistance (X9). These 6 factors have no significant effect because the land area that is owned is too narrow, which is less than $3 \mathrm{~m} 2$ so that the results obtained are low and do not affect the independence of the program. The program is indeed aimed at improving the ability of the community in terms of farming so that they can use the land in maintaining family food.

Another reason for the low participation rate was $(11.11 \%)$ due to the age factor whose work background did not significantly influence. Because with an average age of 44 years, in general housewives at that age are again busy taking care of their families, especially young children, which must be considered continuously. In addition, almost all respondents stated that even though they were not office workers and other workers, there was very little free time because almost all of their domestic work was done on their own, including picking up children in schools and recitations plus social activities in society. Therefore, the implementation of the KRPL program to grow vegetables in the yard, which takes time every day to maintain plants, is often overlooked.

\section{CONCLUSION AND SUGGESTIONS}

Factors that influence the effectiveness of sustainable food house area programs (KRPL) in Banda Aceh City are internal and external factors. Internal factors are (X1) Motivation of participants, $\left(X_{2}\right)$ Participation, $\left(X_{3}\right)$ Area of land, $\left(X_{4}\right)$ Age, $\left(X_{5}\right)$ Education and $\left(X_{6}\right)$ Employment. While external factors are: $\left(X_{7}\right)$ Extension intensity, $\left(X_{8}\right)$ Innovation applied, $\left(X_{9}\right)$ Amount of funding assistance from the government. Based on the results of multiple linear regression known the significance value for the influence of independent variables $\left(X_{1}\right.$, $\left.X_{2}, X_{3}, X_{4}, X_{5}, X_{6}, X_{7}, X_{8}, X 9\right)$ simultaneously on effectiveness $(Y)$ was equal to $0,000<0,05$ and $F_{\text {count }}$ value $4,637>F_{\text {table }} 2.10$ so that it can be concluded that $F_{\text {count }}=$ accepted which 
means there are effects of independent variables $\left(X_{1}, X_{2}, X_{3}, X_{4}, X_{5}, X_{6}, X_{7}, X_{8}, X_{9}\right)$ simultaneously on the dependent variable of effectiveness $(Y)$.

The level of effectiveness of sustainable food house area programs (KRPL) in Banda Aceh was low on the sustainability of the program, the cultivation ability and family food independence. Based on the results of multiple linear regression it is known that the $R$ square value is 0.487 , which means that the influence of variables $\left(X_{1}, X_{2}, X_{3}, X_{4}, X_{5}, X_{6}, X_{7}\right.$, $\mathrm{X}_{8}, \mathrm{X}_{9}$ ) simultaneously on $\mathrm{Y}$ was $48.7 \%$.

\section{REFERENCES}

1. Azwar, S. 2016. Sikap Manusia teori dan pengukurannya. Yugjayakarta; Pustaka Belajar

2. Bahar, Y. H. 2010. Tingkatkan Konsumsi Sayuran Melalui Budidaya Pekarangan. Direktorat Jendral Hortikultura. Jakarta; Kementrian Pertanian.

3. Badan Ketahanan Pangan dan Pelaksana Penyuluhan. 2012. Pengembangan Kawasan Rumah Pangan Lestari (KRPL). Badan Penelitian dan Pengembangan Pertanian. Jakarta; 26 halaman

4. Kementerian Pertanian. 2012. Pedoman Umum Model Kawasan Rumah Pangan Lestari. Jakarta; Kementerian Pertanian.

5. Pearson S., S. Bachri and C. Goatsch. 2003. Is Paddy Farming in Indonesia Still Profit http://www.macrofoodpolicy.com; Februari 2003 (9 Juni 2005).

6. Purwantini, et. al. 2012. Potensi dan Prospek Pemanfaatan Lahan Pekarangan untuk Mendukung Ketahanan Pangan. Jurnal Forum Penelitian Agroekonomi; Volume 30 No 1: 13-30.

7. Saliem HP. 2011. Kawasan Rumah Pangan Lestari (KRPL): Sebagai Solusi Pemantapan Ketahanan Pangan. Konggres IImu Pengetahuan Nasional (KIPNAS); Jakarta. 8-10 Novembar 2011. 